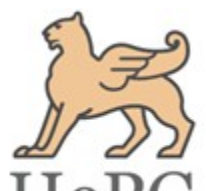

\title{
Taxonomic studies of Bartramiaceae from district Mansehra (Pakistan)
}

\author{
Mazhar-ul-Islam ${ }^{1}$, Jan Alam ${ }^{1}$, Muhammad Fiaz ${ }^{1}$, Mohsin Ali $^{1}$ and Habib Ahmad ${ }^{2 *}$ \\ ${ }^{1}$ Department of Botany, Hazara University, Mansehra-Pakistan \\ ${ }^{2}$ Department of Genetics, Hazara University Mansehra-Pakistan
}

Article history

Received: 2 September 2015

Accepted: 17 September 2015

Published online: 1 October 2015

(C) Islam et al. (2015)

Editors

Afroz Alam

Dipjyoti Chakraborty

Publisher

Horizon e-Publishing Group

Corresponding Author

Mazhar-ul-Islam

$\triangle$ mazharawanhu@gmail.com

\begin{abstract}
This paper deals with the taxonomic studies of the family Bartramiaceae, Bryophyta, from Mansehra district, Khyber Pakhtoonkhaw province, Pakistan. Extensive field surveys were conducted from October 2012 to December 2014. Previously collected specimens hosted at Pakistan Museum of Natural History (PMNH) were also consulted. Keys (at generic and specific level), description, general distribution and foot notes have been provided. Six species were recognized in this study from the area.
\end{abstract}

\author{
Keywords \\ Bartramiaceae; Khyber Pakhtoonkhaw; Mansehra; Pakistan
}

Islam, M., Alam, J., Fiaz, M., Ali, M. and Ahmad, H. 2015. Taxonomic studies of Bartramiaceae from district Mansehra (Pakistan). Plant Science Today 2(4): 138-144. http://dx.doi.org/10.14719/pst.2015.2.4.145

\section{Introduction}

The bryofloristic studies in Pakistan have been neglected and stay behind in past without any apparent reason. Only few workers have contributed their efforts in this direction. Initially, few Europeans bryologists made collection from the North Western Himalayan region (Brotherus, 1898a; Bartram, 1955; Froe1iech, 1964), Chitral (Stormer, 1954), Gilgit (Dixon, 1926) and the Hindukush range (Dixon, 1926; Blatter and Fernandez, 1929; Herzog, 1939). Later on, some Japanese workers made collections from Himalayan and Karakorum regions (Noguchi, 1956 \& 1959; Noguchi, 1964; Deguchi, 1984; Higuchi, 1991; Hasegawa, 1993; Nishimura et al., 1993a; Nishimura et al., 1993b; Nishimura and Higuchi, 1994; Higuchi and Nishimura, 2003). Recently few European bryologists again concerned and investigated the bryoflora of Pakistan (Solman, 2008; Gruber and Peer, 2012).

All these previous efforts collectively revealed the occurrence of about 450 species of bryophytes in Pakistan. Of these, 353 (i.e. 78.45\%) are mosses, 92 liverworts (20.51\%) and 3 hornworts (0.67\%). Further, it is interesting to note that these workers mostly focused the North Western Himalayan region of the country and published their findings in the form of checklists only. Therefore, further extensive field studies in different regions of Pakistan are important in order to explore the bryophyte diversity and distribution patterns of the taxa at the country level.

Members of the family Bartramiaceae are commonly known as "Apple Mosses", distinguished by more or less globose furrowed capsules and distal portion of leaves with prorulose cells (Griffin, 2012). It is fairly large family represented by 10 genera and 420 species, mainly distributed in Montana tropical. During a taxonomic exploration of past, 18 new species were reported under this family from Western Melanesia (Virtanen, 2000). Recently, Philonotis angustiretis Broth., has been reported from West Himalayas (Pakistan) as a new species (Koponen, 2015). Nishimura and Higuchi (2003) reported 3 genera and 9 species under the family Bartramiaceae in Pakistan. 


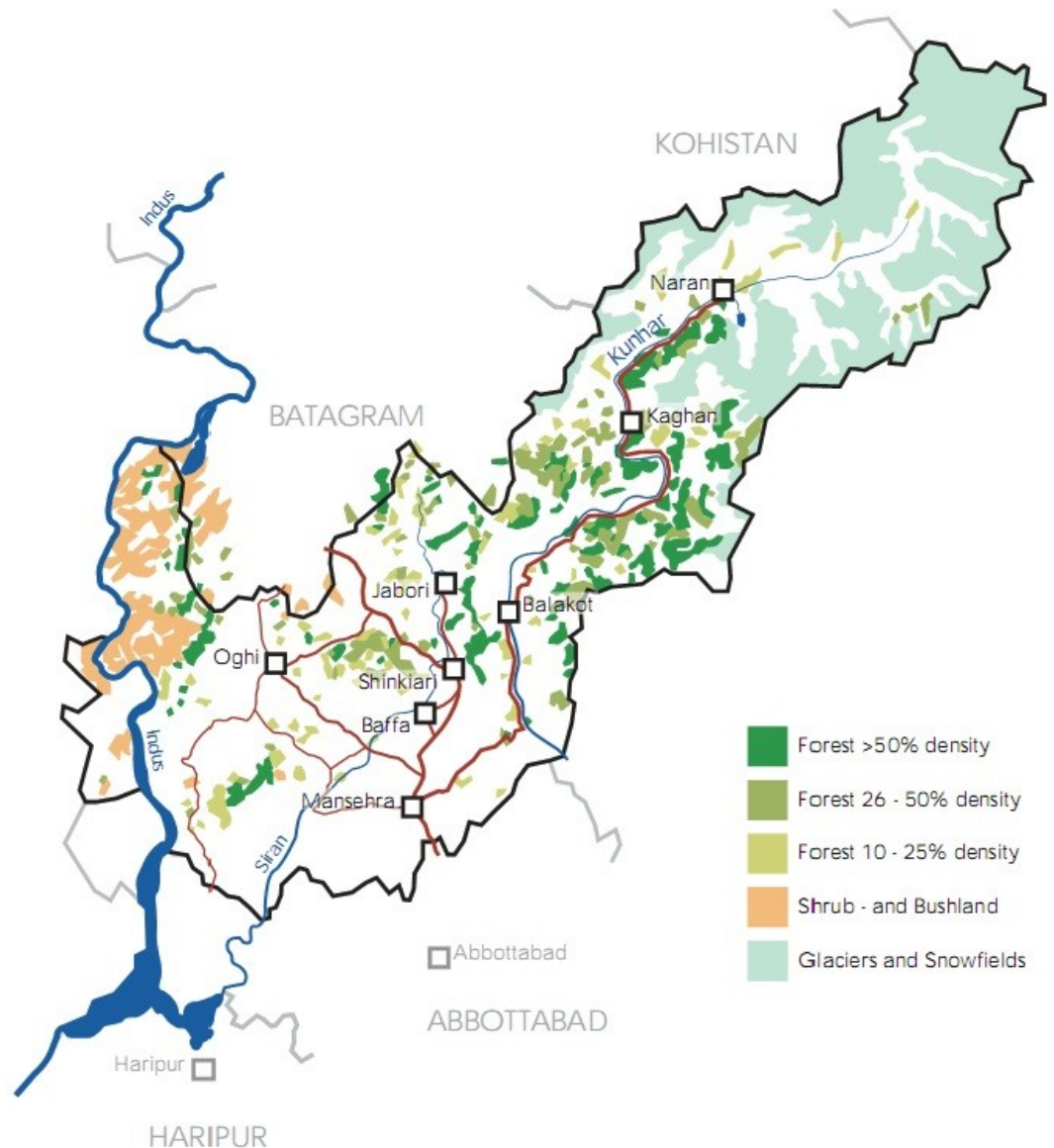

Fig 1: Map of Mansehra District

In current studies, taxonomic investigation of the family Bartramiaceae from Mansehra District has been done. This is based on extensive field observations. Descriptions, keys, general distribution of each species and foot notes have also been given.

\section{Materials and Methods}

\section{a) The Study Area}

The district Mansehra falls under the North Western Himalayan region of Pakistan. The district is situated between $34^{\circ}-14^{\prime}$ to $35^{\circ}-11^{\prime} \mathrm{N}$ and $72^{\circ}-49^{\prime}$ to $74^{\circ}-08^{\prime}$ $\mathrm{E}$ with an altitudinal ranges from $450-5400 \mathrm{~m}$ and covers an area of 4,579 $\mathrm{Km}^{2}$. Northern border of the area is surrounded by Kohistan and Batagram districts. Muzaffarabad is situated on the eastern side, Tor Ghar and Buner Shangla districts are located on western side, while southern boundary is delimited by means of Abbottbad and Haripur distract (Anonymous, 1998; Fig. 1).

\section{b) Experimental Design}

Initially, available relevant literature was reviewed. Specimens of the family hosted at Pakistan Museum of Natural History (PMNH) were systematically consulted. Based on the findings, field trips were conducted in various localities of the district from October 2012 to December 2014. Plant material was collected in plastic zip bags and given a separate collection number for each specimen. Habitat, substrate, habit was also photographed. Collected specimens were dried in blotting paper, kept in the special envelops (4 x 6 inch) and were properly labeled. Small quantity of each specimen was separately preserved for identification. Each specimen was examined under stereoscope and microscope at Cryptogamic Lab, Hazara University and identified with the help of relevant literature. Finally, specimens were deposited in the Cryptogamic Lab, Hazara University Herbarium (HUP).

\section{Results and Discussion}

In this study, from the district Mansehra, total 6 species were observed under 2 genera i.e. Bartramia Hedw., and Philonotis Bridel with 3 species each. Descriptions, keys, general distribution, and foot notes have been given provided.

\section{Bartramiaceae Schwägr}

Plants in loose tufts or sods. Stem straight or decumbent, simple, fastigiate or with subfloral branches. Leaves ovate-lanceolate to lance-subulate, erect-appressed to spreading-recurved, linear, acuminate, acute or obtuse, occasionally abruptly inflated and clasp at base, unbordered or slightly bordered, toothed distally or all over, teeth single or paired; laminal cells round quadrate to oblong, linear or rectangular, prorulose or mammillose at one or both ends. Sexually dioicous, autoicous or synoicous; perigonia gemmiform or discoid, paraphyses filiform or clavate. Seta terminal usually lateral by innovation, single or clustered. Capsule inclined, horizontal rarely pendulous or erect, subglobose or ovoid furrowed; operculum convex or umbonate. Peristome double, single, rudimentary with 16 

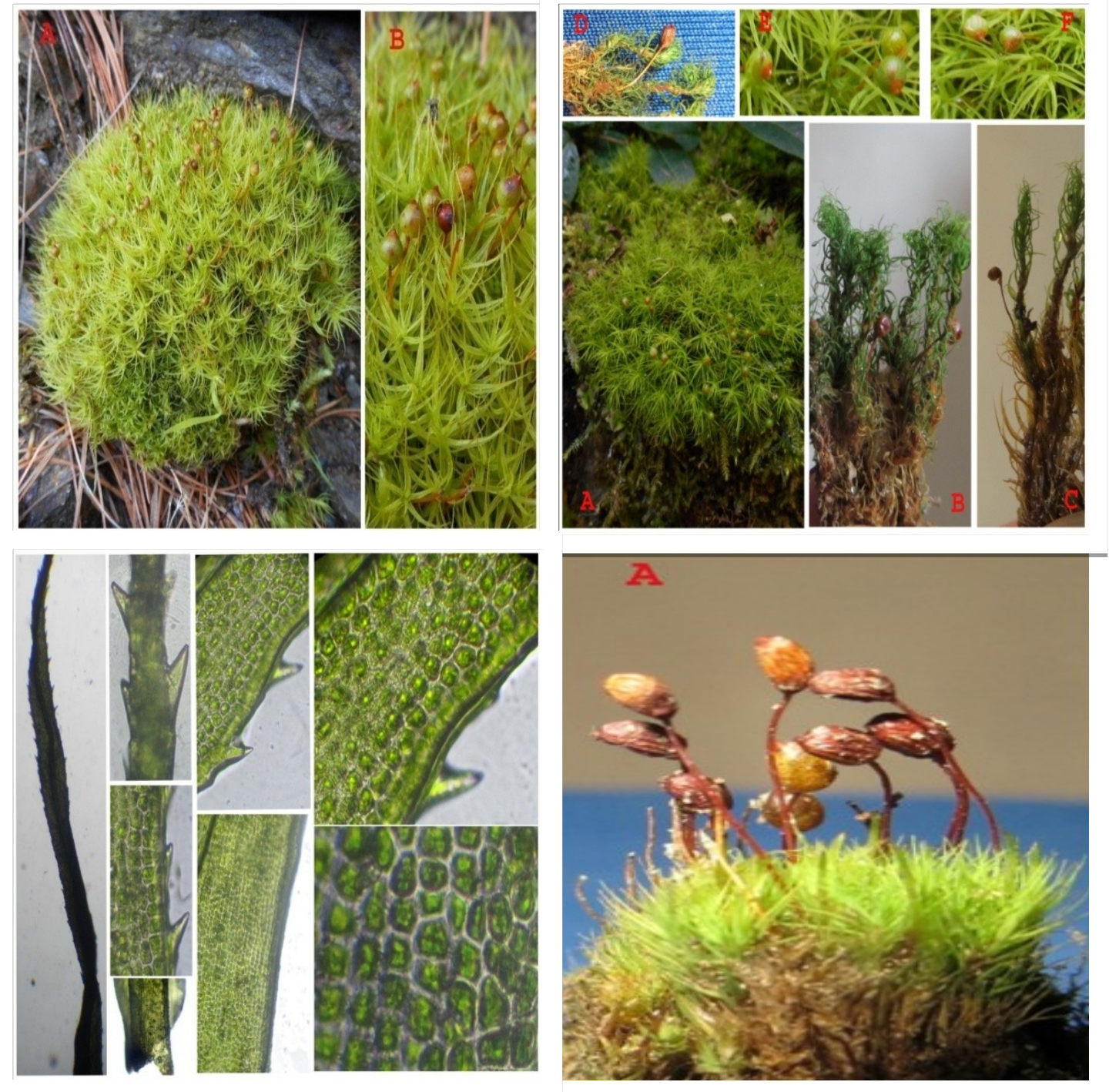

Plate 1: Fig 1 (above left). Bartramia pomiformis: A, habit; B, close up of leaves and capsules, Fig 2 (above right). Bartramia halleriana: A, habit; B, C, D, few individuals with sporophytes hidden among leaves; E-F, close up of capsules, Fig 3 (below left). Bartramia halleriana: Leaf with different parts, Fig 4 (below right). Bartramia ithyphylla (Habit).

lenceolate teeth or lacking. Calyptra cucullate, naked and smooth. Spores spherical to reniform, papillose. Two genera found to occur with 3 species each.

\section{Keys to genera}

1+ Leaves with sheeting base; Lamina 2-3-stratose at margin Bartramia

- Leaves non sheathing at base; Lamina 1-stratose at margin. Philonotis

Bartramia Hedwig, Sp. Musc. 164. 1801.

Plants in loose to crowded, soft or firm tufts, dull green to glaucous, yellowish or yellowish brown, radiculose proximally. Stems erect, often forked. Leaves erect-appressed, slenderly lanceolatesubulate; lamina 2-3-stratose at margins; margin with single or paired teeth; costa usually strong and prominent, distal laminal cells small, subquadrate to oblong linear, prorulose on both surfaces; base sheathing or not, cells elongate to rectangular or linear. Sexually dioicous, autoicous or synoicous; perigonia gemmiform; perichaetial leaves little differentiated. Seta elongate, rarely short and erect. Capsule usually inclined, asymmetric or symmetric. subglobose, with oblique mouth; operculum convex, beaked; peristome double or single. Spores reniform to subspherical, papillose, $15-40 \mu \mathrm{m}$.

Three species were recognized for this genus.

\section{Keys to species}

$1+$ Leaf base silvery white and shiny.........B. ithyphylla

- Leaf base not silvery and shiny. .2

2 + Seta 2-6 mm long; Capsules hidden among leaf........ B. halleriana

- Seta 7-25 mm long; Capsule not hidden and well exposed. B. pomiformis 

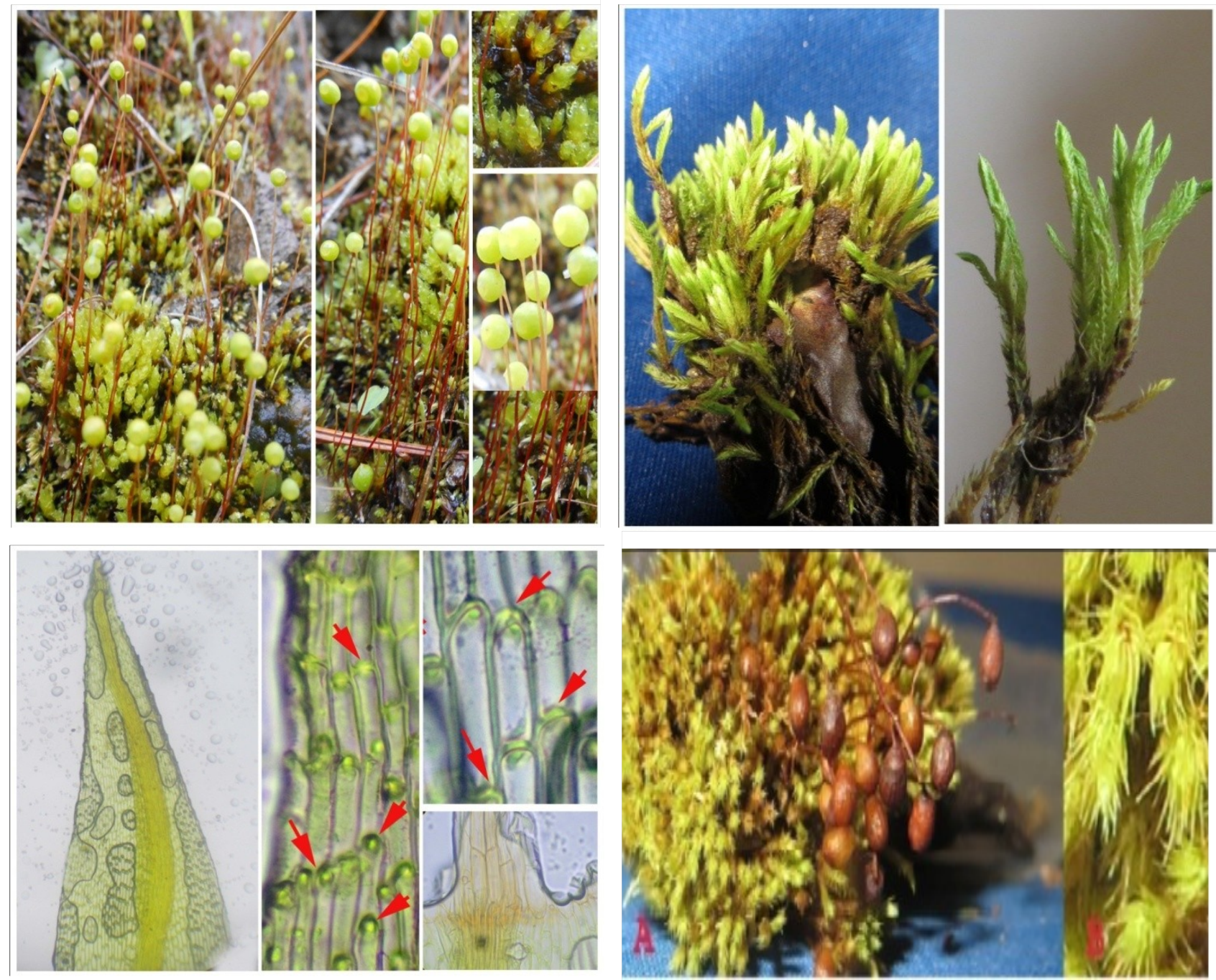

Plate 2: Fig 5 (above left). Philonotis marchica: habit and close up of sporophytes, Fig 6 (above right). Philonotis falcata: Gametophyte, Fig 7 (below left). Philonotis falcata: Leaf; red arrows showing prorulose condition at distal part of the cells, Figure 8 (below right). Philonotis fontana: A, habit; B, close up of shoots.

1) Bartramia ithyphylla Bridel, Musc. Rec. 2(3): 132. 1 f. 6.1803.

Plants soft green to glaucous, in tufts. Stems $12-25$ $\mathrm{mm}$ long. Leaves linear subulate from a straight clasping bottom; margins smooth, entire proximally, serrulate to serrate distally, distal teeth regularly paired; costa excurrent in a slim tip, unclear in distal portion; base silvery white, basal laminal cells with thin-walled, distal cells 23-45 long and 5-7 $\mu \mathrm{m}$ wide. Perichaetial leaves 4-7 mm long and $1-1.8 \mathrm{~mm}$ wide, clasping. Seta 6-28 mm long. Capsule inclined to cernuous, asymmetrical, subglobose to ovoid, 1-1.5 $\mathrm{mm}$ long, furrowed; operculum slightly conical with blunt beak; peristome double with lanceolate teeth, 290-390 $\mu$ m long, papillose proximally, smooth above; segments smooth. Spores globose, $22-41 \mu \mathrm{m}$, roughly papillose.

Specimens examined: Kaghan valley; Babusar Pass, 4181 m, 18.09.2014., Mazhar-ul-Islam \& Ashfaq Ali 838 (HUP). Diamer, 3500 m, 07.10.1992, T. Nakaiki 720 (PMNH).
Habitat: On soil under dry rocks in alpine zone.

General Distribution: North America, South America Europe; Asia (Taiwan, China, India and Pakistan) and Africa.

Bartramia ithyphylla is an alpine species founds in high dry mountains in the study area. This species can be easily recognized from other species by its glistering white leaf base. This feature is more prominent in dry material.

2) Bartramia pomiformis Hedwig, Sp. Musc. 164. 1801

Plants green, grow in dense tufts. Stem $5-80 \mathrm{~mm}$ long. Leaves erect to erect-spreading as moist condition, linear-lanceolate or scarcely lanceolate with subulate apex; margins revolute from bottom to roughly toothed distally, teeth paired; costa excurrent, irregular abaxially in the distal portion, spinose in excurrent tip; basal laminal cells thinwalled; median and distal cells 4-15 $\mu \mathrm{m}$ long and 4-8 $\mu \mathrm{m}$ wide. Seta erect, flexuose, 7-25 mm. Capsule 
asymmetrical, globose to ovoid furrowed, 1.5-2.5 mm long; operculum conical; peristome double; teeth lanceolate, 360-446 $\mu \mathrm{m}$ long, granulose-papillose; cilia present, weakly developed. Spores 20-26 $\mu \mathrm{m}$, papillose.

Specimens examined: Kaghan valley; Shogran, 2545 m, 12-05-2013., Mazhar-ul-Islam Jan Alam, Abdul Majid \& Ashfaq Ali 838 (HUP).

Habitat: On moist shady rocky slope in pine forest.

General Distribution: North America, South America, Europe, Asia (India, Pakistan China), Africa.

Narrowly lanceolate to linear-lanceolate leaves, the elongate seta and the capsule above the foliage makes this species distinctive from $B$. halleriana.

3) Bartramia halleriana Hedwig, Sp. Musc. 164. 1801; Higuchi, M. \& Nishimura, N. In: J. Hattori Bot. Lab. 93: 273-291. 2003.

Plant green to yellowish brown, in dense tuft. Stem 10-150 mm long. Leaves 6-7 mm long and 1-1.2 mm wide, curved or crisped in dry condition, erect spreading as moist, long subulate, narrowly lanceolate, base thinly sheathing; margins revolute from distal side to high in acumen entire proximally, denticulate. Seta 3-7 mm long, terminal generally, single elongate. Capsule subglobose to pyriform, asymmetrical, furrowed, $1.5-2 \mathrm{~mm}$ wide mostly hidden in leaves. Calyptra cucullate; operculum conical convex; peristome double; teeth lanceolate, 500-530 $\mu \mathrm{m}$, reddish brown, proximally granulose, cillia weakly developed. Spore $20-22 \mu \mathrm{m}$.

Specimen examined: Konsh valley; Sathan Gali, 1867 m, 26.04.2014., Mazhar-ul-Islam, Mohsin Ali, Jan Alam, Ibad Ali, Suhail Karim \& Ashfaq Ali 135 (HUP).

Habitat: Grows on moist shady slope in Pinus wallichiana forest.

General Distribution: North America, South America, Europe, Australia, New Zeeland, Asia (India, Pakistan, China).

Bartramia pomiformis Hedwig, Sp. Musc. 164. 1801; Crypt. Fl. Pak. 2: 289.1993.

Plant green to glaucous, rarely yellowish, in dense tufts. Stem 5-80 mm long. Leaves flexuose to crisped as dry, laxly erect to erect-spreading as moist, scarcely lanceolate to linear-lanceolate with subulate apex; margins revolute from bottom to distal acumen, entire at base, roughly toothed distally, teeth paired; costa excurrent, irregular abaxially in the distal portion, spinose in excurrent tip; basal laminal cells thin-walled all over; median and distal cells 4-15 $\mu \mathrm{m}$ long and 4-8 $\mu \mathrm{m}$ wide. Seta erect, flexuose, 5-25 $\mathrm{mm}$. Capsule asymmetrical, wrinkled, globose to ovoid, 1.5-2.5 mm long; operculum conical; peristome double; teeth lanceolate, 360-446 $\mu \mathrm{m}$ long, granulosepapillose; cilia present, weakly developed. Spores 20 $26 \mu \mathrm{m}$, papillose.

Specimens examined: Konsh valley; Sathan Gali, 1867 m, on Soil or rocks 26-04-2014., Mazhar-ul-Islam, Mohsin Ali, Jan Alam, Ibad Ali, Suhail Karim \& Ashfaq Ali, 120 (HUP).

Habitat: On moist shady rocky slope in Pinus wallichiana forest.
General Distribution: North America, South America, Europe, Asia (India, Pakistan, China), Africa.

Philonotis Bridel, Bryol. Univ. 2:15. 1827

Plants hygrophilic, in dense to lax tufts. Stems erect, simple or forked with subfloral whorl of branches. Leaves in several rows, or in 5 rows, 1-stratose, scarcely lanceolate, acute to acuminate, rarely obtuse; margins smooth or revolute, serrulate, teeth single or paired; costa subpercurrent to excurrent; distal laminal cells subquadrate to oblong or linear, prorulose at distal ends on both surfaces, rarely with a centric papilla; basal cells usually more lax than distal cells; alar cells usually absent. Sexually dioicous, less often autoicous or rarely synoicous. Perichaetia terminal or lateral by innovation. Seta solitary, straight or flexuose. Capsule globose to ovoid, erect to horizontal or inclined, furrowed, mouth oblique; operculum conical convex; peristome double or lacking; teeth lanceolate, densely papillose, trabeculate. Spores spherical to reniform, densely and usually coarsely papillose.

Philonotis can be recognized by the 1-stratose leaves typically prolulose and the subfloral whorl of branches on fertile plants. While leaf cells are typically prorulose on sterile stems.

\section{Keys to species}

1 + Leaf not carinate; distal leaf cells prorulose on lower end..... P. fontana

- Leaf slightly or strongly carinate; distal leaf cells prorulose at the upper end. ..2

2 + Leaves strongly carrinate; leaflets of brood branches acute; costa $90-100 \mu \mathrm{m} . . . .$. . f falcata

- Leaves slightly carrinate; leaflets of brood branches acuminate. P. marchicha

Philonotis marchica (Hedwig) Bridel, Bryol. Univ. 2:23. 1827. Mnium marchicum Hedw., Spec Musc. 196. 1801.

Plants small, yellowish green tufts. Stems rigid, simple or cleft, 10-60 mm long. Leaves 1-2.3 mm long, erect-spreading as dry, rather divergent when moist, occasionally spiraled, triangular-lanceolate, acuminate, keeled; margins plane or sometimes narrowly revolute, serrulate nearly to base, teeth single; costa percurrent to long-excurrent; distal laminal cells linear oblong, 20-30 $\mu \mathrm{m}$ long and 4-8 $\mu \mathrm{m}$ wide, prorulose, prorulae smoothed, near the distal ends of cells or rarely at both ends, basal cells oblong, 18-45 $\mu \mathrm{m}$ long and 6-15 $\mu \mathrm{m}$ wide. Asexual reproduction by propagulae rarely borne in leaf bases. Sexually dioicous; perigonia discoid. Seta 15-40 $\mathrm{mm}$ long. Capsule 1-2.5 mm. Spores 20-30 $\mu \mathrm{m}$, papillose.

Specimens examined: Konsh Valley; Sathan Gali, $2545 \mathrm{~m}$, on Soil or rocks 12.05.2013., Mazhar-ul-Islam, Jan Alam, \& Mohsin Ali 838 (HUP).

Habitat: On wet soil and rocks near springs in Pinus willichiana forest. 
General Distribution: North America, Central America; South America; Europe; Asia (India, China, Pakistan); Africa; Atlantic Islands.

Philonotis marchica is characterized by the slightly carinate leaf, singly serrulate leaf margins and the laminal cells bearing smoothed prorulae near the distal ends.

Philonotis falcata (Hook.) Mitt., J. Linn. Soc. Bot. suppl. 1: 62. 1859. Bartramia falcata Hook., Trans. Linn. Soc. London 9: 317, 27 f. 4. 1808.

Plant cylindrical, medium size, $30-40 \mathrm{~mm}$ long, pale colored; Leaves 1-2 mm long and 0.2- $0.8 \mathrm{~mm}$ wide, on short innovations, imbricate, straight in dry condition, falcate, crinate, in five rows (it seen best in wet condition or in clear water), from base broadly triangular or ovate and gradually pointed towards apex; margins plane, basal marginal leaf cells smooth, with thin protuberant outer wall, middle margin uniserrulate or in regularly geminate by protuberant cell corners, distal margins uniserate; Costa $75-100 \mu \mathrm{m}$ broad at leaf base, excurrent or percurrent, with small or few papillae or bulging cell corners at apical part, smooth costa is present on distal side of base; lower basal cells are little bit mammillose but clearly differentiated from upper cells, those have mammillose or papillae at distal end of cells, mammilla and papilla absent in proximal region. Middle laminal cells thick walled and rectangular or quadrate, while basal cells thin walled, distal laminal cells pointed and narrowed.

Specimen examined: Konsh Valley; Sathan gali, 1867 m, 26.04.2014. Mazhar-ul-Islam, Mohsin Ali, Jan Alam, Ibad Ali \& Danish Hayat 119 (HUP). Mansehra; Sharan forest, $2400 \mathrm{~m}, 19.10 .1992$. Nishimura 9720 (PMNH).

Habitat: In moist shady places.

General Distribution: North America, Central America, South America; Europe; Asia (India, China, Pakistan); Africa; Atlantic Islands.

As mentioned earlier that there is no taxonomic information regarding the bryophytes of Pakistan except few check lists (Nishimura et al., 1993; Nishimura and Higuchi, 1993; Higuchi and Nishimura, 2003). In these lists, only two species viz., Philonotis falcata and P. fontana have been reported from Mansehra district. However, current study is a first attempt in which a detailed taxonomic treatment has been provided for the family at district level in Pakistan. Further these types of studies are required to draw a clearer picture of the flora.

Philonotis fontana (Hedwig) Bridel, Bryol. Univ. 2:18. 1827.

Plant medium 55-67 mm long; gametophyte is 25-35 $\mathrm{mm}$ long, they have subfloral whorl leaves, perichaetial leaves obtuse; Stem leaves, erect to erect spreading, less commonly crenulate, sometime falcate, lanceolate to broadly ovate-lanceolate, ovatesubulate, abruptly narrow to acute or acuminate apex; Margin revolute; Costa, short-long excurrent; basal cell rectangular polygonal, tips cell linear, central marginal cells linear; Sexual condition, plant dioicous, perigonia discoid. Sporophyte $30-32 \mathrm{~mm}$. Seta $30-31 \mathrm{~mm}$. Capsule, inclined horizontal, globose- ovoid, length size 2-2.2 mm long, width $1.2 \mathrm{~mm}$, Spore ovoid to reniform, size length $20-25 \mu \mathrm{m}$ long, width, 16-2um.

Specimen examined: Manoor Valley, $2424 \mathrm{~m}$, on soil or wet soil, 26.04.2013. Mazhar-ul-Islam, Ashfaq Ali \& Asmat Ullah 432 (HUP).

Habitat: In moist shady places.

General Distribution: North America, Central America, South America; Europe; Asia (India, China, Pakistan); Africa; Atlantic Islands.

\section{Acknowledgements}

We would like to express our especial gratitude to Prof. Dr. Gruber Johann Peter, Salzburg-Austria for kindly providing old literature in connection to the Bryophytes of Pakistan. We are obliged to Prof. Dr. Manzoor Hussain, Chairman, Department of Botany, Hazara University for various facilities. Dr. Mujtaba Shah, In charge, Hazara University Herbarium is also acknowledged for providing herbarium facilities during lab work. M. Phil. scholars, Ashfaq Ali, Danish Hayat, along with Suhail Karim and Ibad Ali are also acknowledged for their assistance during field surveys.

\section{References}

Anonymous. 1998. District census report of Mansehra. pp. 1-1.

Bartram, E. B. 1955. Northwestern Himalayan Mosses. Bull Torrey Bot Club 82: 22-29.

Blatter, E. and J. Fernandez. 1929. Waziristan Mosses. J Indian bot Soc 10: 143 -153.

Brotherus, V. F. 1898a. Contributions to the bryological flora of the North-Western Himalaya. Acta Soc Sci Fenn 24: $1-46$.

Dixon, H. N. 1926. Mosses collected in Gilgit, etc., by J. Garrett and W. Lillie. Rec Bot Surv India 9: 303 -313, incl. plate 1 .

Dixon, H. N. 1929. Mosses collected in Waziristan by Mr. J. Fernandez in 1927. J Bombay Nat Hist Soc 35: 278 283.

Fransén, F. 2004. A Taxonomic Revision of Bartramia Hedw. Section Bartramia 29 (3): 113-122.

Froehlich, J. 1964. Bryophyten aus Afghanistan und Nordwest-Pakistan. Ann. Nat. hist. Mus. Wien 67: $149-158$.

Gruber, J. P. and T. Peer. 2012. The bryophyte flora of the mountains of North Pakistan. Herzogia 25(2): 271285. http://dx.doi.org/10.13158/heia.25.2.2010.271

Hasegawa, J. 1993. Anthoceratae collected in Pakistan. In: Cryptogamic Flora of Pakistan. Nakaike, T. \& Malik, S. (Eds.), Islamabad 2: $215-219$.

Herzog, T. 1938. Bryophyta. In: Botanische Ergebnisse der Deutschen Hindukusch-Expedition 1935. Feddes Repert. Spec. Nov. Regni Veg. Beih. 108: 3-12.

Higuchi, M. 1992. Mosses from Pakistan collected by botanical expedition of National Science Museum, Tokyo. In: Cryptogamic Flora of Pakistan. Nakaike, T. \& Malik, S. (Eds.), Islamabad, 1: $245-259$.

Higuchi, M. and N. Nishimura. 2003. Mosses of Pakistan. J Hattori Bot Lab 93: 273 -291.

Karczmarz, K. 1980. Bryophytes from Western Jammu and Kashmir. Annales UMCS Sec. C Bilogia 35: 33 - 41. 
Koponen, T. 2015. Notes on Philonotis (Bartramiaceae, Musci). 14. Philonotis angustiretis, species nova, from N.W. Himalaya. Arctoa 24: 24-26

Koponen, T. E. A. Ignatova, O. I. Kuznetsova, and M. S. Ignatov. 2012. Philonotis (Bartramiaceae, Bryophyta) in Russia. Arctoa 21: 21-62.

Mizutani, M., T. Furuki, K. Yamada, and M. Higuchi. 1994. Hepatics from Pakistan collected by the botanical expedition of the National Science Museum Tokyo in 1990. Bull Natl Sci Mus, Tokyo, Ser. B, 20: 143-150.

Nishimura, N. and M. Higuchi. 1993. Checklist of mosses of Pakistan. In: Cryptogamic Flora of Pakistan, Vol. II. Nakaike T. \& Malik S, (Eds.). National Science Museum, Tokyo. p. 275 -279.

Nishimura, N. and M. Higuchi. 1994. Additions to the checklist of mosses of Pakistan. Proc Bryol Soc Japan 6: 98 -99.

Nishimura, N., R. Watanabe, H. Kanda, N. Takaki, U. Mizushima, Z. Iwatzuki, T. Seki, and M. Higuchi 1993b. Pleurocarpous Mosses from Pakistan. In: Cryptogamic Flora of Pakistan, Vol. II. Nakaike T. \& Malik S, (Eds.). National Science Museum, Tokyo. p. $255-268$.

Nishimura, N., Z. Iwatsuki, T. Matsui, N. Takaki, and H. Deguchi. 1993a. Acrocarpous mosses from Pakistan. In: Cryptogamic Flora of Pakistan, Vol. II. Nakaike T. \& Malik S, (Eds.). National Science Museum, Tokyo. p. 239-254.

Noguchi, A. 1959. Mosses from Pakistan. 2. J Hattori Bot Lab 21: 292-295.

Noguchi, A. 1964. A list of mosses from Kashmir and Pakistan. Candollea 19: 191-198.

Robinson, H. 1965. A small collection of bryophytes from Kashmir. Bryologist 68: 313 -320.

Sollman, P. 2008. Several additions to the moss Flora of Pakistan. Trop Bryol 29: 51-53.

Størmer, P. 1954. Mosses from Tirich Mir. Nytt Mag Bot 3: $213-226$.

Townsend, C. C. 1993. New records and a bibliography of the mosses in Pakistan. J Bryol 17: 671- 678. http://dx.doi.org/10.1179/jbr.1993.17.4.671

Townsend, C. C. 1994. A small collection of mosses from Himalayan Pakistan. J Bryol 18: 181-185. http://dx.doi.org/10.1179/jbr.1994.18.1.181.

Virtanen, V. 2000. Taxonomic studies of the Bartramiaceae (Bryopsida) Publications in Botany from the University of Helsinki 31: 1-34. 